tioner on the site, and how they can help to recuce une possible $20 \%$ preventable deaths in transit.

In my area the present policy of the accident service has produced a Gilbertian situation. The police, who are the organizers of the medical care at an incident, have been advised by the Medical Officer of Health that it is undesirable to inform a local general practitioner of an accident near him if the patient is alive, as this would cause delay in treatment by the accident hospital unit. However, the local doctor may well be informed if the patient is dead-to certify death.

Factual evidence of saving life, when a doctor has attended on site at an accident by chance, has made no impression on this policy. In this practice three, possibly four, lives have been saved during the past few years in the small percentage of accidents attended. Admittedly there are pros and cons on the subject. But any local accident medical organization that has as its policy " call the local doctor if the patient is dead, but don't call him if he's alive" must be suspect.

Some of us hope that a wind of change may start blowing through the opinions of the higher echelons of the accident service organizers as a result of Dr. Easton's talk.I am, etc.,

Burley,

Ringwood, Hants.

ROBERT HOWARD.

REPERENCB

1 Howard, R., f. Coll. Gen. Practit., 1965, 9, 48

\section{Mercury Perchloride in Surgery of Bowel Cancer}

SIR,-Mayo Robson ${ }^{1}$ drew attention to the problem of seedling implantation in radical cancer surgery. To avoid this implantation during mastectomy Sampson Handley ${ }^{2}$ advised flushing the wound with $1: 2000$ perchloride of mercury solution. Miles ${ }^{\mathrm{s}}$ used a stronger 1:500 solution of perchloride of mercury after radical resection of the rectum, for its antiseptic rather than its anticancer action.

The use of the solution as an anticancer agent in colon and rectal surgery was popularized by several workers ${ }^{4-6}$ and has been found efficacious. Keynes ${ }^{6}$ stated that there was no evidence of mercury poisoning in any of the cases he had studied, but he gave no details of blood or urinary mercury levels. Royle $^{7}$ described a case of alleged mercury intoxication following the use of $200 \mathrm{ml}$. of 1:500 perchloride solution during the excision of a tumour of the renal pelvis, and this report prompted study of the question.

Six patients with rectal adenocarcinoma were studied (see Table). The urine output of mercury and the blood level of mercury were measured pre- and post-operatively. The technique of rectal restorative surgery employed was essentially that described by Goligher $e t$ al. ${ }^{4}$ In this about 1 litre of 1:500 mercury perchloride solution is used to wash out the rectal stump, while a further $300 \mathrm{ml}$. is used to mop the lumen of the proximal colnn when it is divided, and also to wash the edge of the mesentery and the exposed perirectal tissues in which malignant cells released by lymphatic division and direct tumour extension may lie.

When radical resection was performed the cut edge of the mesentery, the perirectal and perineal tissues, and the divided proximal end of the colon were mopped with the solution, which was dried up before the abdomen was closed. Again the surgeon was alluwed only $300 \mathrm{ml}$. of 1:500 mercury perchloride for all these needs.

\begin{tabular}{|c|c|c|c|c|}
\hline \multicolumn{5}{|c|}{ Details of Patients Studied } \\
\hline No. & Sex & Age & $\begin{array}{l}\text { Clinical } \\
\text { Details }\end{array}$ & $\begin{array}{l}\text { Maximum } \\
\text { Urinary } \\
\text { Mercury } \\
\text { Cuncen- } \\
\text { tration } \\
\text { ( } \mu \text { g./litre) }\end{array}$ \\
\hline 1 & $\mathbf{F}$ & 54 & $\begin{array}{l}\text { Carcinoma rectosigmoid } \\
\text { Restorative resection }\end{array}$ & 58 \\
\hline 2 & $\mathbf{M}$ & 74 & $\begin{array}{l}\text { Carcinoma rectal } \\
\text { ampulla } \\
\text { Abdominoperineal } \\
\text { resection }\end{array}$ & 26 \\
\hline 3 & $\mathbf{M}$ & 50 & $\begin{array}{l}\text { Adenoma sigmoid colon } \\
\text { Local resection }\end{array}$ & 24 \\
\hline 4 & $\mathbf{M}$ & 66 & $\begin{array}{l}\text { Carcinoma rectal } \\
\text { ampulla } \\
\text { Abdominoperineal } \\
\text { resection }\end{array}$ & 24 \\
\hline 5 & $M$ & 60 & $\begin{array}{l}\text { Carcinoma rectosigmoid } \\
\text { Solitary metastases } \\
\text { dome of bladder } \\
\text { Restorative resection } \\
\text { with partial cystect- } \\
\text { omy and wide pelvic } \\
\text { fat clearance }\end{array}$ & 232 \\
\hline 6 & $\mathbf{F}$ & 66 & $\begin{array}{l}\text { Carcinoma rectal } \\
\text { ampulla } \\
\text { Abdominoperineal } \\
\text { resection }\end{array}$ & 38 \\
\hline
\end{tabular}

Details of the six patients studied are shown in the Table, and the results are shown graphically (see Fig.). No patient showed clinical evidence of mercury intoxication, and six of the cases showed an inappreciable uptake of mercury into the blood. Case No. 5, however, showed higher urine values than the others, which were possibly due to the mercury put inside the bladder and "contaminating "the urine, to the more extensive pelvic dissection and the difficulty of drying the mercury out adequately, or to a selective uptake of mercury occurring in the bladder. Because the blood levels were only slightly raised we suspect that the first of these possibilities was responsible. Thus mercury fixes exposed cells such as those in the bladder, and these would be shed over the ensuing days, leading to the higher urine levels demonstrated in this case. Though the evidence for increased mercury uptake by bladder epithelium is slight, three previous cases of mercury intoxication involving bladder surgery are reported by Page and Wilson, ${ }^{8}$ though they used mercury oxycyanide.
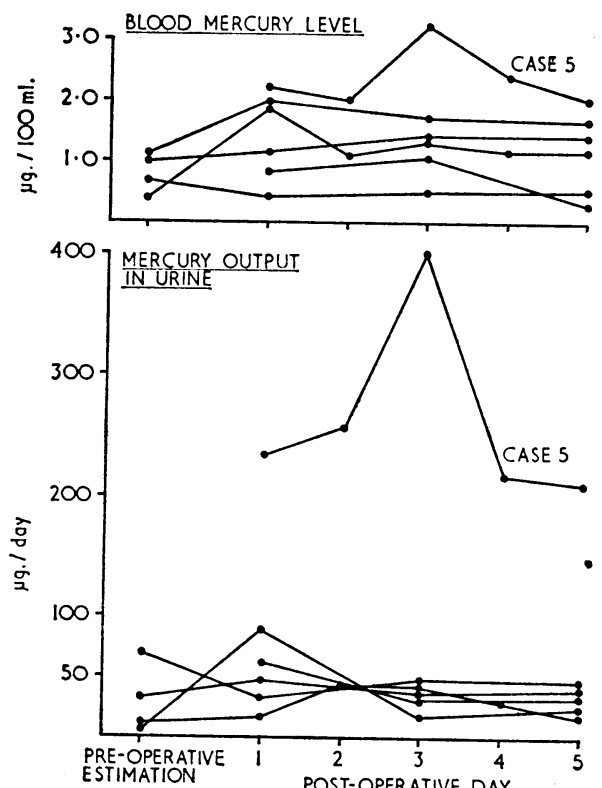

Lane $^{9}$ states that the normal urine mercury content is up to $80 \mu \mathrm{g} . / \mathrm{l}$., and that quantities in excess of $100 \mu \mathrm{g} . / 1$. are abnormal. Moreover, he further points out that symptoms of mercurialism develop when the level exceeds $300 \mu \mathrm{g} . / 1$. The highest level found in the series was $232 \mu \mathrm{g} . / \mathrm{l}$. in Case No. 5 within 24 hours of operation. No patient, however, showed any signs of mercunalism, and it is therefore concluded that mercuric perchloride is a safe anticancer agent when it used, as described above, in large bowel surgery.

I am grateful to Mr. R. W. Nevin and $\mathbf{M r}$. H. E. Lockhart Mummery for permission to study patients under their care and to Dr. R. B. McSwiney for biochemical facilities.

-I am, etc.,

\section{Dept. of Surgery, London S.E.1.
Thomat \\ H. Brendan Devlin.}

\section{REFERENCES}

Robson, Mayo, Bradshaw lecture Royal College of Surgeons, England, 1904.

Handley, $\mathrm{S}$ in Modern Operative Surgery Miles. W. E., Cancer of Rectum, p. 61, 1926,

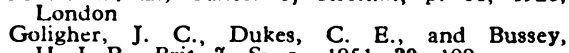

H. J. R., Brit.' J. Surg., 1951, 39, 199

Morgan, C. N., f. Roy. Coll. Surg. Edinb., 1955, 1. 112 .

7 Keynes, W. M., Ann. Surg. 1961, 153, 357.

7 Royle, J. P., Aust. NZ. I Surg., 1964, 34, 71.

640.

- Lane, R. E., Brit. Med. F., 1954, 1, 978.

\section{Elusive Popliteal Pulse}

SIR,-You have done an important service to your readers (5 August, p. 326) by raising a matter of such practical importance, and, while the consensus of opinion is that there are several best ways of palpating for the popliteal pulse (19 August, p. 495), no mention is made of a much more exact technique for obtaining the information which the popliteal pulse is meant to supply. I refer to oscillometry.

Like sphygmomanometry, oscillometry greatly enhances the accuracy of what at best can be regarded as only a subjective impression.-I am, etc.,

\section{Surgical Professorial Unit, London E.C.1.
Lospital \\ Nalidixic Acid and Intracranial Hypertension}

F. E. WEALE

Sir,-In a letter (5 August, p. 370) Dr. $O$. D. Fisher reports a case of raised intracranial pressure in a child during treatment with nalidixic acid. He states, "In the present case the dosage of nalidixic acid prescribed for the infant was twice the recommended one of $100 \mathrm{mg}$. per $\mathrm{kg}$. body weight per day, and this was used in the second course to see if the condition could be reproduced."

The dose of $60 \mathrm{mg} . / \mathrm{kg}$. body weight is the one recommended by us and is the one which appears regularly in our literature. On this basis you will see that the doses used in the case reported by Dr. Fisher were in fact over three times the recommended dose of $60 \mathrm{mg} . / \mathrm{kg}$. body weight. 